\title{
VIOLENCE AGAINST MEN AS MODERATED BY COUPLE'S SELF-CONTROL CONFIGURATIONS ${ }^{1}$
}

\author{
JIŘÍ BURIÁNEK \\ Department of sociology, Faculty of Arts, Charles University \\ E-mail: jiri.burianek@ff.cuni.cz
}

\begin{abstract}
In this paper we adhere to the view that the boundaries between common couple or situational violence and criminal act in the sense of the legal definition of the domestic violence are not totally sharp. The key thesis of general theory of crime (Gottfredson, 2005) about the importance of self-control we can develop so that the reasonable selfcontrol can act as a protective factor on the side of the men as victims of intimate partner violence. Our question is whether the individual characteristics of both actors do not create specific composition (configuration), which operates in the form of conflicts, or may encourage the emergence of IPV. For good reasons, however, we think more about the mediation role of these self-control configurations. We can justify it by the assumption that higher self-control in the case of men can support the state in which the victim is overestimating his own potential and manifested even patronizing attitude towards the offender. Our 5 item typology reconstructed for a representative sample of Czech men $(\mathrm{N}=1001)$ demonstrates some special effects of asymmetric configurations. On the other side the calamity configuration based on the lack of self-control on both sides appears still as the most risky. The level of victimization of men seems to be similar if compared to women and their chance to solve the problem is limited due to some specific reasons which are discussed as well.
\end{abstract}

Key words: partner violence; men; self-control

In the concept of domestic violence (as it is used in both current research and therapeutic contexts) violence per se is rather a metaphoric notion. It includes different phenomena, such as power, control and manipulation. This scope of actions is wide enough to encompass specific forms of permanent control, coercion, manipulation, humiliation, etc. (Gelles, 2003). Violence against men can be distinct slightly due to the lack of an "evident" predominance of power on the part of the perpetrator. On the other hand, there can be a strong potential of manipulation or power of rather a symbolic nature. Therefore, when dealing with it, one can not only swap the offender's and victim's genders.

There are a lot of theories explaining the origins of partner violence those "genderneutral" among them is the general theory of crime (Gottfredson, 2005). It would be easily deducted that at side of the offender we can reckon with a reduced degree of selfcontrol. If it is true that in the cases of typical IPV there is always the factor of power and control over the other's behavior in the background, it might be the impact of reduced

\footnotetext{
1 Supported by scheme PROGRES Q15.
} 
self-control not so evident, because we deal - at least partly - with an aggression targeted, controlled and prudently managed. Lower self-control should thus be closer to common intimate partner violence (as observed using survey methodology). Naturally, some conflicts or attacks involve a situation in which the roles of an offender and a victim are shifting (Winstok, 2007) but it would not be fair to say that the constellation is mostly symmetrical and that consequences of violence do not matter. To label a certain type of partner violence as "common" (Johnson, 1995; Čírtková, 2008) is only acceptable in order to avoid an inappropriate criminalization of any conflict. The monitoring and differentiation of various forms and consequences of intimate partner violence (IPV) remains a challenge for both research and considerations on the quality of life in a given society. Therefore, it is desirable to attempt to capture not only criminal, but also borderline forms of IPV using survey methodology. Moreover, data about real couples are still rare.

In this article we will stick to the view that the boundaries between regular partner or situational violence and criminal act in the sense of the legal definition are not totally sharp and clear. Its main aim is not to test the hypothesis of the impact of reduced selfcontrol on the part of perpetrators on domestic violence. Because we are interested in women as perpetrators, it could help us to avoid the reproduction of the archetypal notions of women as irrational and emotion-ridden creatures that idea accompanied the beginnings of criminology in the $19^{\text {th }}$ century.

Our opinion about the importance of self-control we can turn so that the reasonable self-control can act as a protective factor on the side of the victim. As a climax of this reflection, the question is whether the individual characteristics of both actors do not create specific composition (configuration), which operates in the form of conflicts, or may encourage the emergence of IPV. For good reasons, however, we think more about the mediation role of these configurations. Because this is the first attempt to capture this dimension of the couple dynamics this is of course a highly exploratory procedure. The task of intended analysis will be find configurations, describe them and outline the contexts of domestic violence.

Unlike the first attempt in this field (see Buriánek, Pikálková, \& Podaná, 2015), we focus mainly on men as victims, and to a broader spectrum of possible associations. We can justify it by the assumption that high self-control on the part of men can support the state in which the victim is overestimating their own potential and manifested even patronizing attitude towards the offender.

\section{Researching violence against men: a symmetry question}

Intimate violence against men represents a proverbial "dark figure" of crime and it emerges as a challenge for the empirical study. Their capacity to deal with a situation where there is violence on the part of woman-partner is limited and conditioned on it, whether he wants to inform anyone about the problems. The topic of domestic violence links criminology with the theories of the family and intimate relationships (Giddens, 1992) and it used to be interpreted as a purely private intimacy issue. In a late modern society, partner life is currently still quite idealized by both individuals and the public (Berger \& Berger, 1983), because it is considered as an alternative to the world out there, 
which is governed by a cruel competition under strict rules that transcend the individual. Also for this reason, over quite a long period of time, this area remained outside the scope of legislative norms. Although a partnership should be free from calculation and tendencies to put one's own interests first, it forms a part of the "gender-based power field" (Radimská 2003): this important accent has been made by feminist criminologists, who drew attention to power distribution and control motivations of violence in intimate relationships (e.g., Dobash \& Dobash, 1979; Pagelow, 1984). However this fact supported a common sense imagination that a man as an object of partner violence represents an absolute exception, maybe a grotesque upheaval of his traditional role.

The domestic violence has been investigated since the late 1970s (e.g., Walker, 1979; Straus, Gelles, \& Steinmetz, 1980). Nevertheless, there are only few attempts to study IPV in a comparative dimension, although the evidence has been done that there are substantial cultural differences in features of IPV incidents, their perception and the response to them (see Johnson, Ollus \& Nevala, 2008; Levinson, 1989). Moreover, the majority of IPV research focuses on male-to-female partner violence, but there is a growing body of research indicating that female-to-male IPV violence is far from exceptional. Some scholars have even found larger extent of violence perpetrated by females (see the metaanalysis elaborated by Archer, 2000). In this context, research should not only concentrate on prevalence and incidence rates of IPV, but it should also examine its severity, the consequences and the motivations, as well as situational aspects and the couple dynamics (e.g., Tjaden \& Thoennes, 2000; Walklate, 2001; Dobash \& Dobash, 2004; Johnson, 2006; Chan, 2012).

Thinking about violence against men evidence, the current situation is rather modest: only some minor pilot studies (Lenz, 2006; Jungnitz, 2004) or data derived from victimological surveys are available (see Heiskanen \& Ruuskanen, 2011), mostly concerning Scandinavian countries. As member of the team with Straus \& Gelles, S. Steinmetz published an essay entitled The battered husband syndrome (Steinmetz, 1978), which was a kind of alternative to the battered woman syndrome (Walker, 1979). The study revealed that during the last year $16 \%$ of the couples saw various forms of recurrent violence. In half of the cases, the role of aggressor and victim alternated and also in couples with nonshifting roles the proportion of men and women was similar (see also Čírtková, 2010).

One of the greatest promotors of the symmetry hypothesis (cf. Archer, 2002; Kimmel, 2002) concerning the prevalence was Murray A. Straus (e.g., Straus, 2010). Straus' theory of dyadic concordance with the central hypothesis of gender symmetry of IPV (Straus, 2014) examined who in the relationship is the aggressor (the man, the woman, or both), and the symptomatic conclusion was that most couples at risk of violence are "symmetrical", no matter if the information is reported by men or women (Winstok \& Straus, 2014). Some of these studies, however, are based on second-hand reports, e.g., when students give accounts of their parents' relationship. Obtaining information directly from couples is the best method but often one too complicated and costly. Our current study of selfcontrol configurations represents an alternative way or a substitution in order to combat the limit of individual questioning.

In the Czech Republic, IPV started to be studied only after 1989. The interest in this area has been rising continually (Čírtková, 2002; Martinková, 2001; Voňková \& Huňková, 2004). A comprehensive sociological approach to the phenomenon of violence in the 
family in the Czech Republic was brought by the Safety Risks surveys $(1999,2001)$ and consequently by the International Violence Against Women Survey (IVAWS, conducted in 2003; see Pikálková, 2004; Buriánek \& Pikálková, 2013; Podaná, 2010). Our first study of 1999 noted that $22 \%$ of men and $25 \%$ of women indicated being confronted with "a constant undermining of self-confidence or humiliation by the partner" (Vymětalová, 2001). Methodological experience derived from different surveys was broadly discussed in Buriánek (2013).

In contemporary Czech society, understanding domestic violence or intimate partner violence as a criminal offence is the standard position (Svoboda, 2010). After a wideranging discussion, the Act No. 135/2006 Coll., amending certain laws in the area of protection against domestic violence was finally approved in 2006. It incorporates the measure of temporary expulsion of the offender from a shared flat. The network of helping organisations (intervention centres, etc.) is also expanding. According to Martinková et al. (2014: 20, see also Table 1), between 2008 and 2012 judicial statistics accounted for about 330-420 finally convicted perpetrators of domestic violence a year (proportion of women accounted for roughly $7-10 \%)$.

Table 1: Police statistics on victims of the criminal offence of harassment/abuse of persons living in a common dwelling ${ }^{2}$ - divisions according to the victims' age and gender (Czech Republic, 2004-2012)

\begin{tabular}{|l|c|c|c|c|c|c|c|c|}
\hline Year & $\mathbf{0 - 1 7}$ & $\mathbf{1 8 - 7 0}$ & $\mathbf{7 0 +}$ & $\begin{array}{c}\text { Individual } \\
\text { victims }\end{array}$ & Men & Women & $\begin{array}{c}\text { Group } \\
\text { victims }\end{array}$ & TOTAL \\
\hline 2004 & 5 & 126 & 6 & 137 & 5 & 132 & 58 & 195 \\
\hline 2005 & 10 & 406 & 30 & 446 & 25 & 421 & 251 & 697 \\
\hline 2006 & 12 & 424 & 22 & 458 & 44 & 414 & 183 & 641 \\
\hline 2007 & 15 & 563 & 29 & 607 & 27 & 580 & 207 & 814 \\
\hline 2008 & 16 & 417 & 26 & 459 & 18 & 441 & 150 & 609 \\
\hline 2009 & 16 & 417 & 20 & 453 & 20 & 433 & 141 & 594 \\
\hline 2010 & 12 & 455 & 26 & 493 & 28 & 465 & 180 & 673 \\
\hline 2011 & 19 & 534 & 26 & 579 & 25 & 554 & 196 & 775 \\
\hline 2012 & 13 & 496 & 37 & 546 & 27 & 519 & 138 & 684 \\
\hline
\end{tabular}

Source: Martinková (2014: 15-16)

The reasons for possible underreporting of IPV could be found in different areas (a false definition of the situation by men-victim, willingness to report the case, expected reaction of the police, judges decisions-making). The anticipated result of subsequent steps plays a role here, as judicial practice of divorce proceedings often sees women a bit favored. There is also a possibility influenced by a cultural background even to switch the roles: for a man it brings a risk to be investigated as an offender.

Men do not regard themselves as victims very often (Cook, 1997); they used to be reluctant to admit the facts. They fail to overcome the very first barriers common to all victims of domestic violence (in the respect of the latency in relation to the police and the

2 Art. 199 of the new Czech Penal Code, Art. 215a PC 
judiciary); a second hurdle is represented by specific concerns of abused men of "coming out" (Loseke, 2004). This second latency turns against researchers as well. Lenz (2006) talks about some sort of a silent coalition between victim, abuser and the assistance workers. Such social settings make it very difficult to help men who have become victims of domestic violence, because they become isolated in a fairly extensive manner.

\section{Data and methodology}

The recently finished research on partner violence bears the name Intimate partner violence: follow-up research to IVAWS 2003 and it raises some new questions: "Is violence against men comparable to violence that men commit against women"? (Buriánek, Pikálková, \& Podaná, 2015) "What is the role of stalking in the contemporary Czech society?” (Podaná \& Imríšková, 2016). Therefore, the methodology of the current replication research is based on the two principles, which needed to be integrated: the continuity of the 2003 IVAWS survey, and the possibility of comparing data from two nearly parallel surveys on violence against women and violence against men.

The research of men was carried out by the MillwardBrown agency (in December and January 2012/2013), while using quota selection ( $N=1,001$ respondents) and the CASI method as combined with face-to-face interviews. The sub-project IPV against women included a representative set of 1,502 Czech women aged 18 to 70 ; data was collected by the same agency in June and July 2013. The sampling used the random walk and the CASI/CAPI method. Survey on violence against women included female interviewers only.

The questionnaire included blocks of questions:

- Experience with psychological IPV forms from the current/former female partner (one set of questions at the beginning as the input or "warm-up" set, the other in the second half of the questionnaire, as a tool for comparing data with IVAWS 2003).

- Victimization by physical and sexual violence (based on CTS, including identification of sources, i.e., male as well as female offenders).

- Describing the profile of the most recent violent incident as perpetrated by the female partner.

- The characteristics of a violent partner.

- The characteristics of current partner and a description of the conflicts.

- Experience with family violence in childhood (respondent, partner).

- Experience of stalking, its progress.

In addition to the socio-demographic variables, a series of attitude- and value-related questions was included in the questionnaire:

- Attitudes towards the issue of domestic violence.

- Self-control - both respondents and partners (evaluated by respondents, of course). 


\section{The sample}

In presenting the characteristics of the set we shall emphasize those most related to the topic. The set is representative for Czech men and women aged 18 to 70, controlled by education, economic activity, and other parameters. A minimum of respondents see themselves in highest category of social status (by a subjective estimation - Table 2).

Table 2: A sample set of Czech men $(\mathrm{N}=1,001)$ and women $(\mathrm{N}=1,502)$ in \%

\begin{tabular}{|l|r|r|r|l|r|r|r|}
\hline AGE & \multicolumn{1}{|c|}{ Men } & Women & \multicolumn{1}{c|}{ Total } & \multicolumn{1}{|c|}{ CLASS } & Men & Women & Total \\
\hline $18-29$ & 21.9 & 21.2 & 21.5 & Lower & 9.4 & 6.3 & 7.5 \\
\hline $30-39$ & 24.1 & 25.0 & 24.7 & Lower middle & 32.1 & 31.4 & 31.7 \\
\hline $40-49$ & 18.8 & 22.4 & 20.9 & Middle & 50.5 & 57.0 & 54.4 \\
\hline $50-59$ & 18.4 & 17.0 & 17.5 & Upper middle & 7.6 & 5.2 & 6.2 \\
\hline $60-70$ & 16.9 & 14.4 & 15.4 & Upper & 0.4 & & 0.2 \\
\hline EDUCATION & & & & ECONOMICAL & & & \\
\hline Basic & 7.3 & 5.8 & 6.4 & paid job & 63.2 & 57.2 & 59.6 \\
\hline Middle & 43.6 & 33.6 & 37.6 & self-employment & 13.4 & 7.5 & 9.9 \\
\hline Middle with grade & 32.7 & 47.6 & 41.6 & unemployed & 4.3 & 5.5 & 5.0 \\
\hline & 16.4 & 13.1 & 14.4 & $\begin{array}{l}\text { at household/ } \\
\text { maternal leave }\end{array}$ & 0.1 & 8.6 & 5.2 \\
\hline University level & 0.1 & & 0.0 & studying & 4.8 & 5.6 & 5.3 \\
\hline Other & 100 & 100 & 100 & retired & 13.2 & 15.4 & 14.5 \\
\hline & & & & other & 100 & 100 & 100 \\
\hline
\end{tabular}

Since most of the analyses shall involve partnership, it should be recalled that these questions relate to a large group of respondents. Marital status was stated as follows: $35 \%$ of single men and $25 \%$ of single women, $45 \%$ of married men (52\% of married women), $16 \%$ were divorced. Partner relations create substantial part of the life of most of our interviewees, because $70 \%$ of men and $74 \%$ of women currently live in a relationship. In our sample $26 \%$ of men and $28 \%$ of women had been married at least once before, which corresponds to the relatively high divorce rate in the Czech Republic. In these coexistence patterns no significant differences are usually found between men and women, the only exception in this respect is cohabitation with a partner or friend, which was more often reported by women $(18 \%)$ than by men $(14.5 \%, \mathrm{p}<0.05)$.

\section{Self-control measurement}

The following analysis of self-control relies on the conceptual framework of the general theory of crime (Gottfredson \& Hirschi, 1990, Hirschi \& Gottfredson, 2000). Two central concepts of the theory, namely low self-control and opportunity, explain the stability of individual differences in the tendency to commit crime or other types of behaviour 
that bear similar levels of risk (see also Wikström \& Treiber, 2007; Pratt \& Cullen, 2000; Mutchnick, Martin, \& Austin, 2009). An up-to-date review of methodological debates is provided by Marshall \& Enzmann (2012) along with an outline of the approach to selfcontrol taken by the International Self-Report Delinquency Survey (ISRD).

Grasmick, Tittle, Bursik \& Arneklev (1993) developed a scale which soon became one of the most popular subjective measures of self-control, even if Hirschi and Gottfredson repeatedly rejected it as a universal measure (Hirschi \& Gottfredson, 2001: 230). Originally it was a 24 -item self-report instrument which was intended to reflect the original six dimensions of self-control (see also Arneklev et al., 1999). Following empirical studies demonstrated both the existence of a single underlying factor and an adequate level of reliability (Piquero, 2008).

For the purposes of our surveys, we modified the ISRD2 12-item self-control scale. However, we used an alternative version which was developed for adult respondents by Eurojustis (and verified on a large pilot sample in the Czech Republic). To its eleven items we added another one (the fourth item in Table 3) measuring individual attitudes to conflicts. This item was not excluded from the analysis because it fit seamlessly with the scale, with little cost to its consistency or reliability, especially for women (Cronbach alpha for both subsamples 0.87 ).

Table 3: Self-control scale items (agree or disagree on a scale from 1 to 4)

\begin{tabular}{|l|c|c|c|c|c|c|}
\hline & \multicolumn{3}{|c|}{ Women } & \multicolumn{3}{c|}{ Men } \\
\hline Self-control scale & Mean & S. $d$. & $N$ & Mean & S. $d$. & $N$ \\
\hline $\begin{array}{l}\text { I act on the spur of the moment without stopping to } \\
\text { think. }\end{array}$ & 3.0 & 0.9 & 1269 & 2.9 & 0.9 & 828 \\
\hline $\begin{array}{l}\text { I do whatever brings me pleasure here and now, even } \\
\text { at the cost of some distant goal. }\end{array}$ & 3.0 & 0.9 & 1269 & 2.8 & 0.9 & 828 \\
\hline $\begin{array}{l}\text { If things I do upset people, it's their problem not } \\
\text { mine. }\end{array}$ & 2.6 & 0.9 & 1269 & 2.5 & 0.9 & 828 \\
\hline $\begin{array}{l}\text { No reason to be concerned about conflicts: some can } \\
\text { be fun and effective }\end{array}$ & 2.7 & 0.9 & 1269 & 2.6 & 0.9 & 828 \\
\hline I often prefer to avoid tasks which seem to be difficult & 3.0 & 0.8 & 1269 & 2.9 & 0.9 & 828 \\
\hline $\begin{array}{l}\text { If things I do upset people, it's their problem not } \\
\text { mine. }\end{array}$ & 2.8 & 0.9 & 1269 & 2.8 & 0.9 & 828 \\
\hline $\begin{array}{l}\text { I will try to get the things I want even when I know } \\
\text { it's causing problems for other people }\end{array}$ & 3.3 & 0.8 & 1269 & 3.0 & 0.8 & 828 \\
\hline I lose my temper pretty easily. & 3.0 & 0.8 & 1269 & 2.8 & 0.9 & 828 \\
\hline $\begin{array}{l}\text { When I'm really angry, other people better stay away } \\
\text { from me. }\end{array}$ & 2.9 & 0.9 & 1269 & 2.7 & 0.9 & 828 \\
\hline $\begin{array}{l}\text { I try to look out for myself first, even if it means mak- } \\
\text { ing things difficult for other people. }\end{array}$ & 3.2 & 0.8 & 1269 & 3.0 & 0.8 & 828 \\
\hline $\begin{array}{l}\text { Excitement and adventure are more important to me } \\
\text { than security. }\end{array}$ & 3.3 & 0.8 & 1269 & 3.0 & 0.9 & 828 \\
\hline $\begin{array}{l}\text { I'm more concerned with what happens to me in the } \\
\text { short run than in the long run. }\end{array}$ & 3.2 & 0.8 & 1269 & 3.0 & 0.8 & 828 \\
\hline
\end{tabular}


After the re-categorization of the sum score, the mean value on the $1-10$ scale is 6.9 points for the entire dataset. The distribution leaned slightly toward higher self-control for both genders, more strongly so for women (7.1 points) than men (6.5). While such a result could be expected given women's higher aversion to risk, it may as well be attributed to the social desirability bias.

In order to examine self-control in intimate partners, a shortened Likert scale was constructed from the last four items measuring how the respondents subjectively rated their partner's characteristics. The reliability of the relatively short battery was acceptable, with Cronbach's alpha values of 0.75 (for current partners) and 0.81 (for previous partners) in the entire dataset. The summed scores indicated substantially higher levels of self-control in women's current partners (with a mean value of 11.9 on a scale from 4 to 16), compared to previous partners (10.0); the difference was lower for men (12.1 to 11.0$)^{3}$. This could be expected given people's general tendency to rate their current choices better than those made in the past.

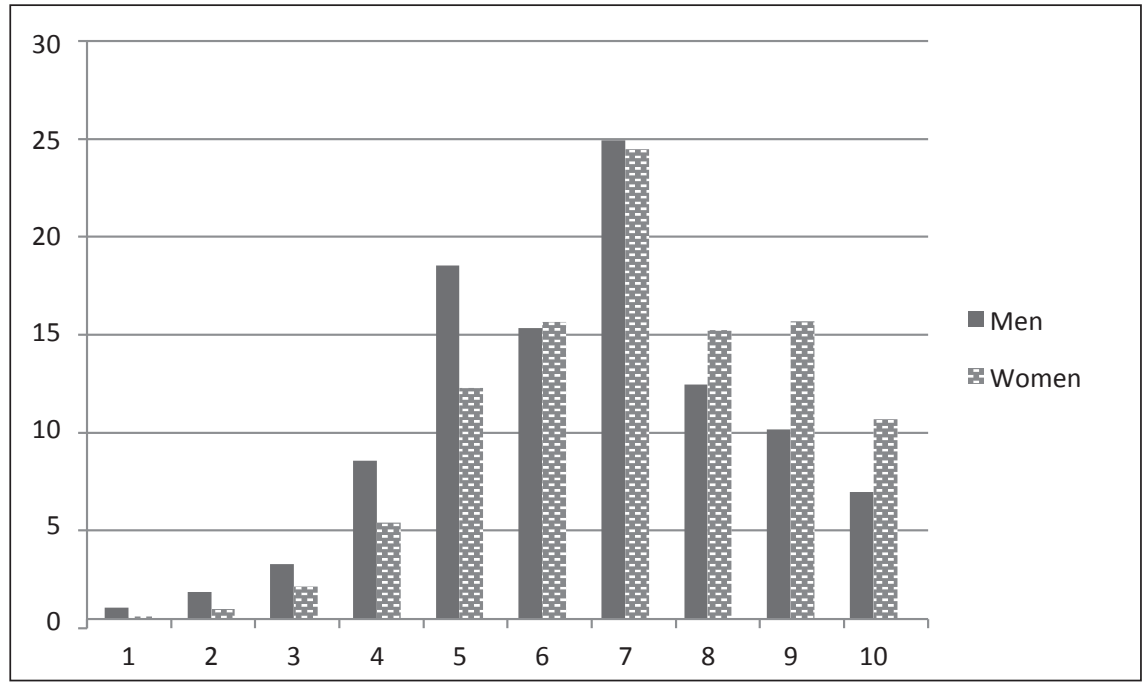

Figure 1: Distribution of self-control (interval variable) $-\mathrm{N}=2479$

Note: difference between men (mean 6.5) and women (7.1) is significant.

\section{Relationship configurations based on Self-Control}

While our dataset does not provide reliable evidence of a gender symmetry in violence (another section of the questionnaire contains merely questions about the aggressor in a single incident and about any instances of retaliation), it helps us measure the level of a/symmetry in self-control. The focus shifts to an independent variable that is correlated

3 After current partner SC scale transformation into the format 1-10 the mean for the men's spouses is 6.9 , for women's partners 6.8 (no significant difference). 
to violence and may represent a relatively strong predictor thereof (although we only have a picture of violence experienced from partners).

The variables measuring self-control were elaborated into a typology of relationship configurations. Our goal was to identify couples that are either homogamous ("birds of a feather flock together") or heterogamous ("opposites attract...”) in terms of self-control. The problem was that the values of respondent's, current partner's and previous partner's self-control are strongly correlated (for current partner is $\mathrm{R}=0.56$ in total sample).

We constructed a simple typology based merely on combinations of respondent's and current partner's self-control (as noticed above our data were not collected from couples and were not based on detailed accounts). Using the explorative method of K-means clustering, we opted for a five categories solution. In addition to the average or symmetrically neutral type, there were the high-control couples (referred to as "+ +") and the calamity couples (with low self-control in both partners), and two asymmetrical options, namely the protective type (with higher self-control on the part of the respondent, who has to be prepared for higher levels of egocentrism and lower levels of self-control in his partner) and the compensational type (with higher self-control on partner's part, as if the respondent was seeking reliable support in his/her partner).

Table 4: Results of cluster analysis: mean values of self-control by cluster and cluster distribution by gender in total sample $(\mathrm{N}=1718)$

\begin{tabular}{|l|c|c|c|c|c|c|}
\hline \multicolumn{1}{|c|}{ Type: } & $(++)$ & $(\mathbf{0}+)$ & $\mathbf{( 0 ~ 0 )}$ & $\mathbf{( + 0 )}$ & $(--)$ & \\
\hline & Positive & Compensational & Average & Protective & Calamity & \\
\hline Self-control & 9.1 & 6.6 & 5.3 & 7.9 & 4.3 & \\
\hline SC_current partner & 9.0 & 7.7 & 5.8 & 5.6 & 3.4 & \\
\hline Men (\%) & 20 & 33 & 21 & 17 & 9 & 100 \\
\hline Women (\%) & 26 & 24 & 17 & 25 & 8 & 100 \\
\hline Total & 23.8 & 27.4 & 18.7 & 21.8 & 8.3 & 100 \\
\hline
\end{tabular}

In the following, we are going to argue that the calamity and protective types have deviant tendencies. For this reason we have recoded the cluster membership to the ordinal continuum: since aggressor's low self-control probably cannot be effectively compensated by higher self-control on the part of the victim, we expect higher prevalence of IPV in the protective configuration. This solution appears plausible, also because women are more likely to belong to the protective type and men to the compensational type. Given evidence of higher levels of self-control in women, our data seem to make an adequate picture of the situation on the partnership market.

With regard of the social background of these configurations, the strength of these determinants is relatively low. The different types can be found in all kinds of social settings, and they likely depend on different psychological mind-sets behind one's choice of intimate partners. The both average and calamity configurations show a relatively lower level in the respect of both partner's age (mean is 40, in total 44) and respondent's age (even same values detected). We measured a relatively weak but statistically significant association with partner's education in the subset of women. There is a higher frequency of positive configurations among women with college-educated partners, and a higher 
frequency of the protective and calamity types among those with low-educated partners. Men with low-educated partners are also more likely to live in a compensational configuration.

\section{Effects of configurations on IPV}

Table 5 shows the results for questions on victimization using a specific formulation typical for CTS scale. It shows lifetime (from the age of 16) prevalence for "slapping, kicking or punching" by anybody and consequently it adds the prevalence of this form caused by current partner.

As known (Buriánek, Pikálková, \& Podaná, 2014; cf. also Killias, Haymoz, \& Lamon, 2006), men are apparently more frequent victims of these forms of physical violence (if also outside-family experience incorporated), while women are mostly assaulted by their own partners (this is more likely the case in both at-risk configurations, men and women alike). Indeed, low self-control in men represents a risk factor in any case (both for him and for his partner).

Table 5: Specific form of life-time victimization by configurations and by gender (percentages)

\begin{tabular}{|l|l|c|c|c|c|c|c|}
\hline & & \multicolumn{7}{|c|}{ Configuration type: } \\
\hline Slapped by: & & Positive & Compens. & Average & Protective & Calamity & Total \\
\hline Lifetime & Men & 35 & 44 & 56 & 34 & 43 & 43 \\
\hline (by anybody) & Women & 11 & 17 & 28 & 27 & 29 & 21 \\
\hline Actual partner & Men & 2 & 4 & 3 & 9 & 21 & 5 \\
\hline & Women & 3 & 12 & 15 & 20 & 25 & 16 \\
\hline
\end{tabular}

Note: Number of respondents "slapped by current partner" 52 in total only, for subset of women difference between clusters not significant.

Couples with symmetrically high self-control appear to be the optimal configuration with highly (albeit not fully) protective effects in the area of violence or abuse. With the exception of aggression in public or restricting access to money by partner, men are more likely to report being victims of different forms of psychological abuse, with those living in a calamity configuration most at risk. Women in protective configurations are more likely to be neglected or devalued (details see in Buriánek et al., 2015). Comparison of selected items describing psychological violence yields similar results. Men in calamity configurations are more often targets of jealousy and they are at higher risk of insults and name-calling. When we summarized risk of psychological abuse into index, the most risk category proportion correlates with a ladder of configurations. As many as $32 \%$ of women living in calamity configurations were at high risk of psychological violence, and almost the exact same gradient (35\%) was measured for the subset of men as well (the overall proportion of $12 \%$ of women and $15 \%$ of men at risk has been detected in the entire sample). 
Table 6: Probability of conflict by gender (means on scale 1-10)

\begin{tabular}{|l|c|c|}
\hline & \multicolumn{2}{|c|}{ Conflict probability: } \\
\hline Configuration & Men & Women \\
\hline Calamity & 4.8 & 3.7 \\
\hline Protective & 3.0 & 2.7 \\
\hline Average & 3.1 & 3.0 \\
\hline Compensational & 2.1 & 2.5 \\
\hline Positive & 1.7 & 1.8 \\
\hline Total & 2.7 & 2.5 \\
\hline$N$ & 661 & 1057 \\
\hline
\end{tabular}

Additionally we can mention the reflection on probability of the occurrence of a violent conflict in current relationship (Table 6). Although there are almost no differences between men and women in total, in calamity configurations about one-fourth of women and even more men admit (with 6 or points more on the ten-point scale) that a violent conflict might occur. We have identified a significant correlation with the general evaluation of the quality of partnership as well (eta $=0.34)$.

\section{A typology refinement}

Because our current analysis focuses exclusively on men it could be useful to precise a bit our typology of configurations. At first it seems to be correct to compare self-control on equivalent items only. It is possible due to the satisfactory reliability of 4-item scale for respondents (Cronbach alpha 0.74). The typology constructed still on explanatory base (both variables keep the mutual correlation on 0.56 ) probably reflect more precisely the point of view of men interviewees and it does not aspire for external comparison.

Table 7: Configuration types redefined for men

\begin{tabular}{|l|c|c|c|c|c|}
\hline & \multicolumn{5}{|c|}{ Cluster (men only) } \\
\hline Self-control short scale & Calamity & Average & Compensational & Positive & Protective \\
\hline SC_Respondent & 7.9 & 11.2 & 10.5 & 14.5 & 13.9 \\
\hline SC_Actual Partner & 7.7 & 10.8 & 13.6 & 14.8 & 10.7 \\
\hline N & 57 & 204 & 95 & 182 & 83 \\
\hline
\end{tabular}

The picture of proportions of separate types among men differs slightly (one fourth has changed position) but it is acceptable to see the rise of the share of positive constellation and the fall down of compensational arrangements. As noticed above we deal with subjective evaluation of both and men tend to see their counter-parts as a bit better selfcontrolled.

There is no influence of education (only among protective a bit higher level is observable) and age (with a slightly higher proportion of category 30-39 by calamities), no effect confirmed in the case of religiosity of partner as well. Following table (8) enables to control clusters by the self-control measure based on full scale and review the estima- 
tion of the probability of partner conflict: the differences seems to be fixed, the probability slightly higher among all types (see table 6). The biggest difference is in satisfaction with the relationship between positive (9.1) and protective arrangement (7.3 on average). Previous partnership evaluation did not offer significant deviations, the subsample is relatively small.

Table 8: Quality of partnership by configurations (means, 1-10)

\begin{tabular}{|c|c|c|c|c|c|}
\hline \multicolumn{6}{|l|}{ Means } \\
\hline $\begin{array}{l}\text { Configuration } \\
\text { type }\end{array}$ & $\begin{array}{c}\text { Self control } \\
\text { (full scale) }\end{array}$ & $\begin{array}{l}\text { Satisfaction in } \\
\text { partnership }\end{array}$ & $\begin{array}{c}\text { Parent } \\
\text { partnership } \\
\text { evaluation }\end{array}$ & $\begin{array}{c}\text { Previous } \\
\text { partnership } \\
\text { evaluation }\end{array}$ & $\begin{array}{c}\text { Probability of } \\
\text { conflict in current } \\
\text { partnership }\end{array}$ \\
\hline Calamity & 4.1 & 8.0 & 7.4 & 6.5 & 4.8 \\
\hline Protective & 7.9 & 7.3 & 7.8 & 5.8 & 3.5 \\
\hline Average & 6.1 & 8.0 & 7.5 & 6.1 & 2.8 \\
\hline Compensational & 5.7 & 8.7 & 8.1 & 6.4 & 2.4 \\
\hline Positive & 8.4 & 9.1 & 8.5 & 6.3 & 1.8 \\
\hline \multirow[t]{2}{*}{ Total } & 6.8 & 8.3 & 7.9 & 6.2 & 2.7 \\
\hline & 620 & 621 & 621 & 372 & 621 \\
\hline
\end{tabular}

Note: Nonsignificant result shaded

We have approved the path dependency of constellations by exploiting information about childhood of our sample of men. Bad conditions stimulate the tendency to opt for calamity configuration and the linear trend is quite clear-cut. The prevalence of violence among parents on the side of partner is in general small (6\% in total, for calamity $12 \%$ ). The divorce of own parents had no effect, the incomplete family only minor effect (calamity $23 \%, 14 \%$ in total).

Table 9: Disadvantages in respondent's childhood by configurations (\%)

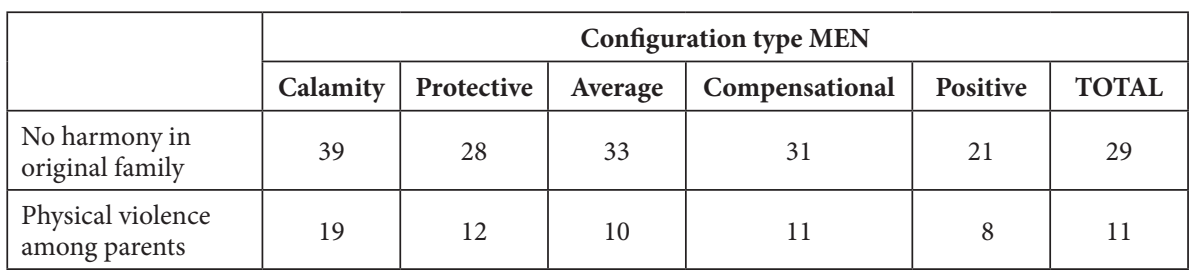

In the statistical sense there is also no significance of binge drinking frequency, although respondents from calamity relationship declared "weekly" in 14\% (overall sample $8 \%$ only). Similar result (not significant) offers the breakdown by configuration for partner binge drinking (Fig. 2).

\section{The associations between configurations and IPV}

In the respect of aggression on the public places which is a strong predictor of IPV risk, calamity configuration contains $7 \%$ of such spouses (in total 1.5\%). Taking into ac- 


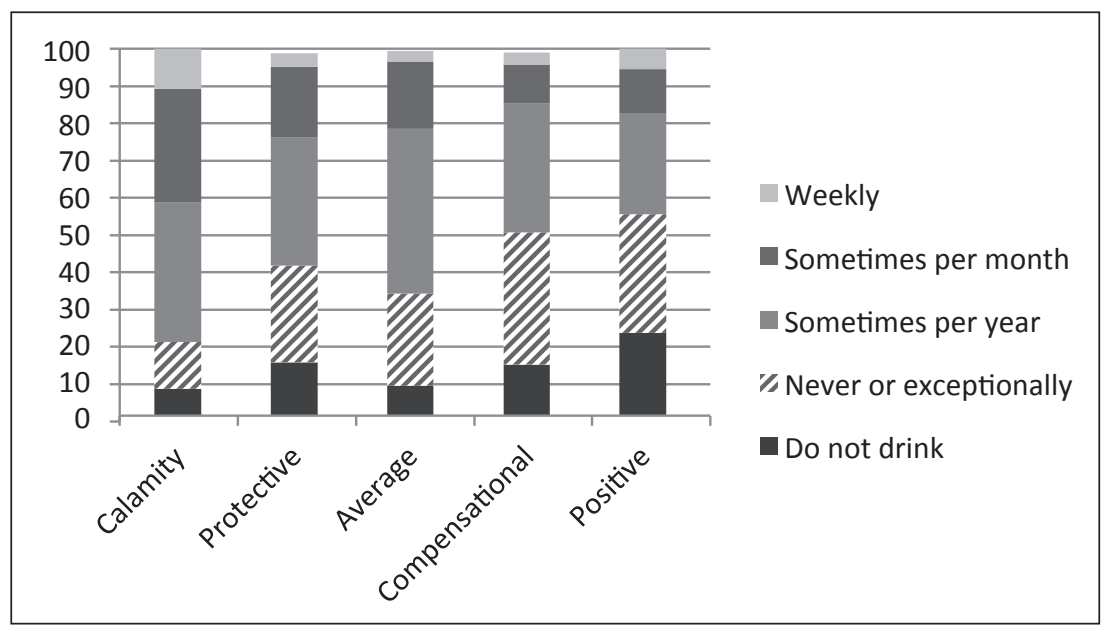

Figure 2: Binge drinking (5 units) frequency in the part of partner by configuration

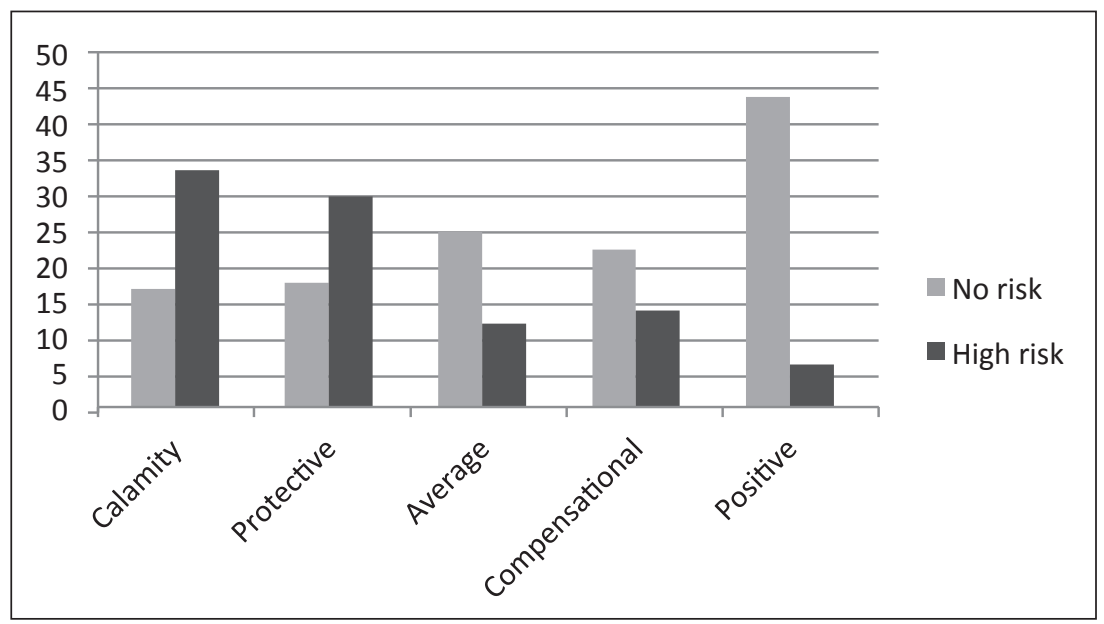

Figure 3: Share of both extreme risk of abuse categories by configurations (\%)

count "Calling names..." the proportion of "always + often" reach up to $11 \%$ by calamity relationships (in total 3\%). On the contrary, the share of "never" category increases from $68 \%$ by calamity up to $93 \%$ by positive balanced couples. Closer contact with "Jealousy" is also observable among calamity couples (19\% "often") and protective ones (17\%, in total $10 \%$ only). We can conclude that calamity configuration opens the space for IPV against men however it is not its ultimate cause because it express the low level of self-control on the side of partner.

Using our index of psychological abuse which covers many typical forms of IPV we have got a chance to separate a high risk category (level five means frequent exposition to different forms of abuse or violence). Figure 3 compare this risk category broken 
down by configurations: the transfer from calamity to positive arrangement illustrates a special impact of configuration.

At the same moment we have to stress that calamity configuration legitimates (when our respondents were asked for a hypothetical situation of a physical attack) a kind of relatively strong response by use physical power.

Table 10: Man's reaction (as estimated) on physical attack by configuration (\%)

\begin{tabular}{|c|c|c|c|c|c|c|}
\hline \multirow[b]{2}{*}{$\begin{array}{l}\text { Solution of potential } \\
\text { spouse-attack }\end{array}$} & \multicolumn{6}{|c|}{ Configuration types - MEN } \\
\hline & Calamity & Protective & Average & Compensational & Positive & Total \\
\hline Even stronger revenge & 2 & 1 & 1 & 2 & 3 & 1,7 \\
\hline $\begin{array}{l}\text { Same way reaction } \\
\text { without escalation }\end{array}$ & 17 & 3 & 3 & 2 & 1 & 3,4 \\
\hline $\begin{array}{l}\text { Limited physical } \\
\text { defense }\end{array}$ & 15 & 18 & 14 & 9 & 10 & 12,5 \\
\hline Other tools to solve & 15 & 20 & 18 & 18 & 14 & 16,9 \\
\hline $\begin{array}{l}\text { Unappropriate to react } \\
\text { on such kind }\end{array}$ & 23 & 30 & 33 & 34 & 36 & 32,9 \\
\hline Escape only reasonable & 28 & 26 & 30 & 33 & 36 & 31,6 \\
\hline \multirow[t]{2}{*}{ Other meaning } & 0 & 3 & 1 & 0 & 1 & 1,0 \\
\hline & 100 & 100 & 100 & 100 & 100 & 100 \\
\hline
\end{tabular}

To resume findings from the last incident descriptions we can mention that in calamity configurations the incidents are serious but the chance for a coming out is relatively lower (there is a skepticism about police capacity to deal with, for example). Table 11 examines alternative measures of the capacity to inform other people (applicable due to more general formulation of the question on current state of arts in general). This enlargement of the subsample brings statistically significant result and reveals an interesting effect of protective configuration. In the whole sample the calamity configuration loses

Table 11: Latency of IPV by configuration in different contexts (\%)

\begin{tabular}{|l|c|c|c|c|c|c|c|}
\hline & \multicolumn{7}{|c|}{ Configuration type MEN } \\
\cline { 2 - 9 } & Calamity & Protective & Average & Compensational & Positive & Total & N \\
\hline Closest people know & 69 & 45 & 18 & 39 & 41 & 37 & 132 \\
\hline $\begin{array}{l}\text { Your friends know } \\
\text { about }\end{array}$ & 53 & 27 & 15 & 17 & 18 & 24 & 132 \\
\hline $\begin{array}{l}\text { Conflicts frequent, } \\
\text { not violent }\end{array}$ & 28 & 22 & 14 & 7 & 3 & 12 & 621 \\
\hline $\begin{array}{l}\text { Initiated mostly by } \\
\text { partner }\end{array}$ & 26 & 31 & 19 & 16 & 9 & 18 & 621 \\
\hline
\end{tabular}

4 Similar, although nonsignificant results can be found concernig expert assistance (8\%), Police help (calamity $11: 2 \%$ in total), family knows (calamity $44 \%$, protective $39 \%$, total $32 \%$ ), colleagues know ( $13 \%$ in total). 
the capacity to hide incident or incidents: the situation of a dramatic "Italian marriage" is usually reflected by closest environment of the couple. Both combinations with a lower level of partner self-control tend to increase frequency of conflicts (mostly non-violent): the role of partner as an originator is out of doubts.

For calamity configuration a ratio between offender's spontaneous motivation and provoked or defensive reaction is $63: 37$ percent, the positive configurations demonstrate $93: 7$, in addition by positive there was no aggression defense type, while one fourth by calamities! It could support the hypothesis that for calamity relationship are more common mutual attacks, in partners with high self-control came about partly intentional conduct.

We do not prefer to come back to extensive measures of life time prevalence of violence because the share of other men as offender is of great importance. Therefore, the role of configuration can't become a crucial one. It can be detected for example in physical threats item (calamity $29 \%$, positive $14 \%$ only, $20 \%$ in total), among calamities is observable a bit higher proportion of partner as actor. The fact that the respondent admits his share on a provocation is not related to the type of configuration ( $26 \%$ in total).

\section{Conclusions}

Pagelow (1984) covers values fixing woman into a violent relationship by the concept of traditional ideology. However, men might also see their way out of the troubled partnership hindered by traditional ideological patterns. The configuration analysis offers the hypothesis that a traditional pattern of expected masculinity could support the over-protective attitudes. In modern non-patriarchal society, the value of parental roles is gaining weight for many fathers as well. The reason may be that they - in part by objective circumstances, in part deliberately - no longer maintain the traditional role of breadwinner. Obviously, emerging organizations defending the rights of fathers (very often divorced individuals) suggest that this may be the sign of a new tradition imaging man as parent apart from a mere contributor to food. However, we have to avoid the misuse of this "new ideology" in cases when a fight for child care emerges as a tool of revenge to his ex-partner.

Men may find it more acceptable to remain in a troubled relationship: if any partner's threat has the potential of an unpleasant consequence (e.g. an escape with children and, paradoxically, a suicide threat), the risk becomes real (cf. Wolf et al., 2003; Buriánek et al., 2006). Therefore, even a seemingly weaker individual is able to manipulate her stronger counterpart, which partly explains the inability of some men to evade a troubled relationship. Simply said, divorce is still considered - despite a kind of its "normalization" - by many men to be a stigmatizing thing. Furthermore, a man leaving his partner can meet various and mostly real risks:

- worries associated with the provision of an alternative residence,

- loss of the children,

- obligation to pay alimony, etc.

Psychological abuse - at the risk level detected by $15 \%$ of Czech males, although rarely streamed directly into a criminal prosecution - could indicate the presence of serious 
violence in the partnership. It affects the satisfaction with the partnership and it could also play a role in the explanation of the high divorce rates in the Czech Republic. The victimization of men offers a lot of similarities if compared to the one of women (cf. Straus, 2006). Because Czech women and men are characterized by high expectations in the respect of values of good partnership (Buriánek, Pikálková, \& Podaná, 2015), a risk factor may lie even in simple ignorance of partner's needs, especially if partner is characterized by higher level of egocentrism and lower level of self-control. According to our data, the impact of lower social status should not be ignored as well (cf. Salmi \& Danielsson, 2014). Even if our knowledge of the configurations of intimate relationships is based on information from one partner per couple only, one conclusion can be made: these configurations establish an important underlying factor of conflicts and psychological abuse. While the effects of (respondent's or partner's) self-control on violence are often neither immediate nor strong, self-control moderates other risk factors (cf., e.g., Wikström \& Treiber, 2007; Rebellon et al., 2008), including the frequency of binge drinking as a typical risky behavior.

If thinking about practical consequences, the art of choosing wisely still plays an important role in partner choice. In line with the general theory of crime of Gottfredson \& Hirschi (1990) or Burton et al. (1998), one should choose with regard to their potential partner's self-control and do not rely on own even high potential. Lower levels of selfcontrol in partner are a risk factor and specific predictor of abusive or violent behavior. However, the coupling scheme seems to be often fixed (at individual level) and the offer of suitable partners always limited. Self-control configurations can play a protective role but the harshest forms of IPV grow up from much more deeper roots.

\section{REFERENCES}

Archer, J. (2000). Sex Differences in Aggression Between Heterosexual Partners: A Meta-Analytic Review. Psychological Bulletin, 126(5), 651-680.

Archer, J. (2002). Sex differences and physically aggressive acts between heterosexual partners: A metaanalytic review. Aggression and Violent Behavior, 7(4), 313-351.

Arneklev, B. J., Grasmick, H. G., \& Bursik, R. J., Jr. (1999). Evaluating the dimensionality and invariance of 'low self-control.' Journal of Quantitative Criminology, 15, 307-331.

Berger, B., \& Berger, P. L. (1983). The War over the Family: Capturing the Middle Ground. Hutchinson Educ.

Buriánek, J. (2013). Violence Against Men as a Challenging Topic for Empirical Research. Pp. 61-70. In: A.Kuhn et al. (eds.), Kriminologie, Kriminalpolitik und Strafrecht aus internazionaler Perspektive, Staempfli Verlag AG Bern.

Buriánek, J., Kovařík, L., Zimmelová, P., \& Švestková, R. (2006). Domácí násilí - násilí na mužích a seniorech. [Domestic violence - violence against men and seniors] Prague: Triton.

Buriánek, J., \& Pikálková, S. (2013). Intimate Violence. A Czech Contribution on International Violence Against Women Survey. Prague: Karolinum.

Buriánek, J., Pikálková, S., \& Podaná, Z. (2014). Násilí na mužích. Sonda do zákoutí partnerských vztahů. [Violence against men. A sondage on secluded places of partner relationships] Prague: FF UK.

Buriánek, J., Pikálková, S., \& Podaná, Z. (2015). Abused, Battered, or Stalked: Violence in Intimate Partner Relations Gendered. Prague: Karolinum.

Burton Jr, V. S., Cullen, F. T., Evans, T. D., Alarid, L. F., \& Dunaway, R. G. (1998). Gender, self-control, and crime. Journal of Research in Crime and Delinquency, 35(2), 123-147. 
Chan, K. L. (2012). Gender symmetry in the self-reporting of intimate partner violence. Journal of Interpersonal Violence, 27(2), 263-286.

Cook, P. W. (1997). Abused Men: The Hidden Side of Domestic Violence. Westport: Praeger.

Č́rtková, L. (2002). Domácí násilí ve faktech a teoriích. [Domestic violence in facts and theories]. Gender - rovné príležitosti - výzkum 1/2002.

Č́rrtková, L. (2010), Muži jako oběti domácího násilí. [Men as victims of domestic violence]. Právo a rodina, 2010(7).

Dobash, R. E., \& Dobash, R. P. (1979). Violence Against Wives. A Case Against the Patriarchy. New York: The Free Press.

Dobash, R. P., \& Dobash, R. E. (2004). Women's violence to men in intimate relationships: Working on a puzzle. British journal of criminology, 44(3), 324-349.

Gelles, R. J. (2003). Violence in the family. Pp. 837-862. In: W. Heitmeyer, \& J. Hagan (eds.), International Handbook of Violence Research. Dordrecht: Kluwer Academic Publishers.

Giddens, A. (1992). The Transformation of Intimacy: Sexuality, Love and Eroticism in Modern Societies. Cambridge: Polity Press.

Gottfredson, M. R. (2005). The empirical status of control theory in criminology. Pp. 77-100. In: F. T. Cullen, J. P. Wright, \& K. Blevins, Taking Stock: The Status of Criminological Theory, Piscataway, New Jersey: Transaction.

Gottfredson, M. R. \& Hirschi, T. (1990). A General Theory of Crime. Stanford, California: Stanford University Press.

Grasmick, H. G., Tittle, C. R., Bursik Jr, R. J., \& Arneklev, B. J. (1993). Testing the core empirical implications of Gottfredson and Hirschi's general theory of crime. Journal of research in crime and delinquency, 30(1), 5-29.

Heiskanen, M. \& Ruuskanen, E. (2011). Men's experiences of violence in Finland 2009. Helsinki: HEUNI. Hirschi, T., \& Gottfredson, M. R. (2000). In defense of self-control. Theoretical Criminology, 4(1), 55-69.

Johnson, H., Ollus, N., \& Nevala, S. (2008). Violence Against Women. An International Perspective. New York: Springer.

Johnson, M. P. (1995). Patriarchal terrorism and common couple violence: Two forms of violence against women. Journal of Marriage and the Family, 57(2), 283-294.

Johnson, M. P. (2006). Conflict and control: Gender symmetry and asymmetry in domestic violence. Violence against women, 12(11), 1003-1018.

Jungnitz, L. et al. (2004). Violence against men. Men's experience of interpersonal violence in Germany. Federal Ministry for Family Affairs.

Killias, M., Haymoz, S., \& Lamon, P. (2006). Swiss Crime Survey. Die Kriminalitaet in der Schweiz im Lichte der Opferbefragung von 1984 bis 2005. Bern, Staempfli Verlang AG.

Kimmel, M. S. (2002). "Gender symmetry" in domestic violence: A substantive and methodological research review. Violence against women, 8(11), 1332-1363.

Lenz, H.-J. (2006). Gewalt gegen Männer als neues Thema in Forschung und Gesellschaft. Pp. 98-116. In: W. Heitmeyer/M. Schröttle (Hrsg.): Gewalt. Beschreibungen, Analysen, Prävention. Bonn: Bundeszentrale für politische Bildung.

Levinson, D. (1989). Family Violence in Cross-Cultural Perspective. Newbury Park: Sage Publications.

Marshall, I., \& Enzmann, D. (2012). The Generalizability of Self-Control Theory. Pp. 285-328. In: J. Junger-Tas, I. H. Marshall, D. Enzmann, M. Killias, M. Steketee, \& B. Gruszczynska, The Many Faces of Youth Crime. Contrasting Theoretical Perspectives on Juvenile Delinquency across Countries and Cultures, New York: Springer.

Martinková, M., \& Macháčková, R. (2001). Vybrané kriminologické a právní aspekty domácího násilí. [Selected criminological and legal aspects of domestic violence] Prague: IKSP.

Martinková, M., Slavětínský, V., \& Vlach, J. (2014). Vybrané problémy z oblasti domácího násilí. [Selected problems of domestic violence]. Prague: IKSP.

Mutchnick, R., Martin, R., \& Austin, W. T. (2009). Travis Hirschi. Pp. 283-326. In: Criminological Thought: Pioneers Past and Present. Upper Saddle River, N J: Prentice Hall.

Pagelow, M. D. (1984). Family Violence. New York: Prager. 
Pikálková S. (ed.) (2004) Mezinárodní výzkum násili na ženách - ČR/2003: př́spěvek k sociologickému zkoumání násilív rodině. [International research on violence against women - CR / 2003: contribution to the sociological exploration of family violence]. Prague: Sociologický ústav AV.

Pikálková, S., Podaná, Z., \& Buriánek, J. (2015). Ženy jako obèti partnerského násilí: sociologická perspektiva. [Women as victims of intimate partner violence: a sociological view] Prague: SLON.

Piquero, A. R. (2008). Measuring self-control. Pp. 26-37. In: E. Goode (ed.), Out of Control: Assessing the General Theory of Crime, Stanford, Cal.: Stanford University Press.

Podaná, Z. (2010). Reporting to the police as a response to intimate partner violence. Czech Sociological Review, 46(3), 453-474.

Podaná, Z., \& Imríšková, R. (2016). Victims' responses to stalking: An examination of fear levels and coping strategies. Journal of interpersonal violence, 31(5), 792-809.

Pratt, T. C., \& Cullen, F. T. (2000). The empirical status of Gottfredson and Hirschi's general theory of crime: A metaanalysis. Criminology, 38(3), 931-964.

Radimská, R. (2003). Moc a individuální zájmy v partnerských vztazích. [Power and individual interests in intimate partnership]. Gender, rovné přiležitosti, výzkum, 4(3-4), 4-5.

Rebellon, C. J., Straus, M. A., \& Medeiros, R. (2008). Self-control in global perspective: An empirical assessment of Gottfredson and Hirschi's general theory within and across 32 national settings. European journal of criminology, 5(3), 331-361.

Salmi, V., \& Danielsson, P. (2014). Intimate partner violence victimization and household financial strain. Journal of Scandinavian studies in criminology and crime prevention, 15(2), 159-166.

Straus, M. A. (2006). Future research on gender symmetry in physical assaults on partners. Violence against women, 12(11), 1086-1097.

Straus, M. A. (2010). Thirty years of denying the evidence on gender symmetry in partner violence: Implications for prevention and treatment. Partner Abuse, 1(3), 332-362.

Straus, M. A. (2014), Bringing couple-level measures and family contradictions into research through dyadic concordance types. Unpublished manuscript. Durham, NH: Family Research Laboratory. Retrieved from http://pubpages.unh.edu/ mas2

Straus, M. A., Gelles, R. J., \& Steinmetz, S. K. (1980). Behind Closed Doors: Violence in the American Family. New York: Doubleday/Anchor.

Svoboda, M. (2010). Pomoc mužùm jako obětem domácího násilí v ČR. [Helping men as victims of domestic violence in the Czech Republic] Prague: Charles University.

Tjaden, P., \& Thoennes, N. (2000). Prevalence and consequences of male-to-female and female-to-male intimate partner violence as measured by the National Violence Against Women Survey. Violence against women, 6(2), 142-161.

Voňková, J., \& Huňková, M. (2004). Domácí násilí v českém právu z pohledu žen. [Domestic violence in Czech law from the perspective of women]. Prague: Profem.

Vymětalová [Pikálková], S. (2001). Domácí násilí: přirozený jev? Sociologický časopis (Czech Sociological Review), 37(1), 103-121.

Walker, L. E. (1979). The Battered Woman. New York: Harper and Row Publishers.

Walklate, S. (2001). Gender, Crime and Criminal Justice. Devon: Willan Publishing.

Wikström, P. O. H., \& Treiber, K. (2007). The role of self-control in crime causation: Beyond Gottfredson and Hirschi's general theory of crime. European Journal of Criminology, 4(2), 237-264.

Winstok, Z. (2007). Toward an interactional perspective on intimate partner violence. Aggression and Violent Behavior, 12(3), 348-363.

Winstok, Z., \& Straus, M. A. (2014). Gender differences in the link between intimate partner physical violence and depression. Aggression and Violent Behavior, 19(2), 91-101.

Wolf, M. E., Ly, U., Hobart, M. A., \& Kernic, M. A. (2003). Barriers to seeking police help for intimate partner violence. Journal of family Violence, 18(2), 121-129. 